\title{
Popliteal-to-distal (PD) bypass versus infragenicular percutaneous transfemoral angioplasty (PTA) to treat limb threatening ischemia
}

\author{
Mohamed E. El Sherbeni, MD; Wael Elshimy, MD; \\ Abdelrahman M. Gameel, MD; Medhat El-Leboudy, MD; \\ Ahmad M. Tawfik MD
}

Vascular Surgery Unit, Zagazig University, Egypt.

Objectives: The purpose of this study is to compare the results of revascularization in a critically ischaemic limb due to infragenicular arterial diseases, using either the conventional bypass operations or endovascular revascularization.

Methods: Over a period from December 2010 and May 2012, forty patients suffering from limb-threatening ischaemia were included in this study; all of the patients had peripheral arterial disease falling into Fontaine III \& IV categories. All patients had extensive infrapopliteal disease (TASC type C\&D). All patients had a good run off at the posterior tibial, anterior tibial or dorsalis pedis. The patients were divided into group A treated by PD bypass surgery and group B treated by endovascular management.

Results: The primary patency rate of group A at 6 months and one year was 77\% and 65\% respectively, with limb salvage rate $80 \%$ after one year follow up. In group B the primary patency rate at 6 months and one year was 65\% and 60\% respectively, with limb salvage rate $75 \%$ after one year follow up.

Conclusions: $P D$ bypass has primary success rate and limb salvage rates higher than infragenicular PTA that might be due to our still growing experience in PTA.

Keywords: Infragenicular angioplasty; popliteal to distal bypass; pedal bypass; critical limb ischaemia.

\section{Introduction:}

Patients with limb-threatening ischemia from severe occlusive disease of the infrapopliteal arteries with reconstitution of a patent distal crural or pedal artery are excellent candidates for distal arterial revascularization. The source of inflow is usually the common femoral artery (CFA), but in selected patients, generally those with diabetes in whom obstructive disease is preferentially in the popliteal and tibioperoneal segments, the inflow site can be the popliteal artery. ${ }^{1}$

The theoretical drawbacks of using a distal inflow source include the presence of haemodynamically significant proximal occlusive disease (especially in the superficial femoral artery) and progression of occlusive disease in the postoperative period. ${ }^{2}$

Although surgical bypass still plays a key role in revascularization of critical limb ischemia (CLI), 3 increasing clinical experience over the past two decades shows encouraging results for primary endovascular strategies, with acceptable feasibility, low complication rates, ${ }^{4-6}$ and high limb salvage rates comparable with surgery.

Diabetic patient, with systemic atherosclerosis, neuroischemic limb ulcers, gangrene, and sepsis (the so-called "diabetic foot syndrome") is prone to a higher rate of periprocedural surgical complications. ${ }^{3,4,7}$ Therefore, endovascular techniques may have many applications in this field because of their low invasiveness, absence of scarring, and lack of need for venous conduits.4,8,9 These strategies seem to have the advantages of enabling simultaneous multiple vessel recanalization with high reproducibility if 
necessary, , $9^{2}$ resulting in shorter hospital stays and health care expenditure.

The Trans Atlantic Inter-Society Consensus (TASC) $)^{10}$ working group developed an alternative classification, in which surgery was advised in cases with TASC type C\&D lesions.

This study aims at comparing the two modalities of treatment (PD bypasses and PTA) in TASC C\&D infrapopliteal lesions and to define the role of tibial PTA in infragenicular lesions as alternative modality of treatment in our unit.

\section{Patients and methods:}

This study was conducted during the period between December 2010 and May 2012 at Zagazig university hospitals. Forty patients suffering from critical limb ischemia were included in this study.

Clinical assessment in the form of complete history taking, full vascular examinations of lower limbs including measurement of Ankle/ Brachial index (ABI) and Duplex ultrasounds as well as arteriography were performed in all patients. Particular attention was paid to proper visualization of distal run off vessels and the appropriate inflow vessel.

Inclusion criteria: (1) Patients that had rest pain or ischaemic ulceration or gangrene (2) preoperative angiographic evidence of severe infrapopliteal disease; either TASC C or D infrapopliteal lesions; (3) Adequate ipsilateral or contralateral saphenous vein ( vein greater than $3 \mathrm{~mm}$ in diameter at preoperative duplex scanning); and (5) no contraindications to anticoagulation therapy.

Exclusion criteria were: (1) patients who were elderly or had poor medical conditions, with life expectancy estimated at less than 2 years. (2) Any stenotic narrowing of the arterial lumen by $25 \%$ to $40 \%$ were considered hemodynamically insignificant, (3) patients with non salvageable feet.

The patients were classified into two groups; A which included 20 patients in whom revascularization was done by using popliteodistal bypass and group B which included 20 patients in whom revascularization was done by infragenicular angioplasty. Open surgery was excluded in case of presence of infection near the site of distal anastomosis in 4 cases, poor general condition in 7cases or patient preference in 9 cases.

In group (A) a short popliteo-distal bypass was done with use of regional anesthesia, either epidural or spinal. Inflow was the popliteal artery above the knee. Vein graft was used in all cases. The reversed technique was used in 15 cases, while the non-reversed translocated technique was used in 5 cases, where there was a size mismatch.

In group (B) percutaneous transluminal angioplasty (PTA) was done (only local anesthesia was used in most cases). Ipsilateral antegrade femoral access was used. A $6 \mathrm{~F}$ sheath was used for delivery of various devices. Terumo guide wire was used for passage across the lesion. The balloon dimensions were chosen according to the size of the artery and the length of the lesion. No stents were used in any of the cases.

In all patients with tissue loss debridement and drainage of any infection was done.

Postoperative management: Postoperative antithrombotic therapy consisted initially of platelet inhibitors (Clopidogrel) and vasodilators (Cilostazol) with intravenous heparin application for one week then the patient was switched to oral anticoagulants depending upon the individual surgeon preference. Graft patency, ABI and the clinical status of the patient, according to Rutherford's (1997) ${ }^{11}$ guidelines, were recorded postoperatively daily during the hospital stay period. After discharge the patients was followed up weekly in the first month then monthly for the first year. During these follow up visits wound healing was observed, pulses were felt regularly, Doppler study of the graft and distal arteries were done, and ankle/Brachial indices were performed. Duplex study was routinely done at 3, 6, 9 and 12 months postoperatively. CT angiography was not done except when complications were suspected.

End points of the study were primary and secondary patency, limb salvage rates, and death. An ABI decrease of more than 0.15 compared with the initial postoperative ABI 

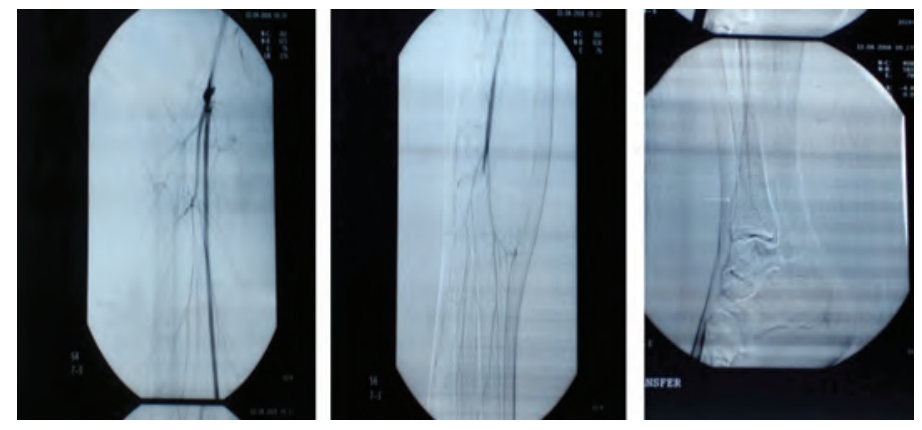

Figure (1): Pre-operative angiography.
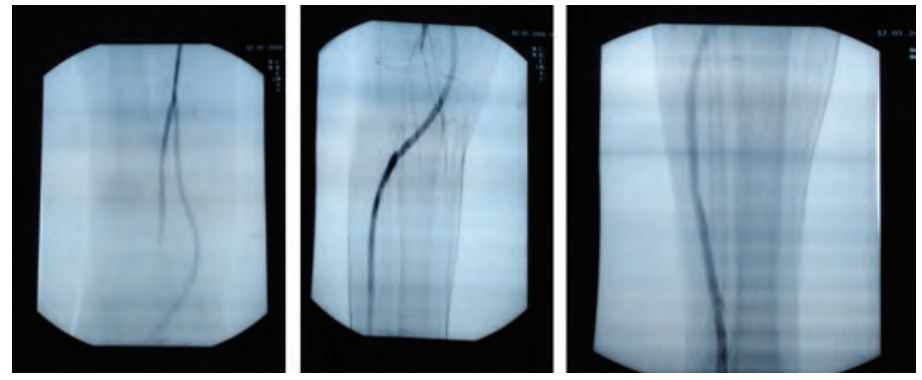

Figure (2): Postoperative angiography showing popliteo anterior tibial bypass.
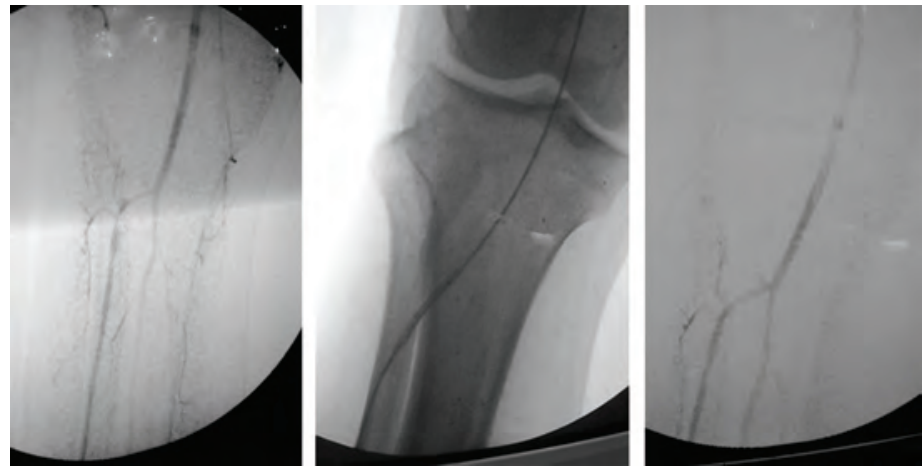

Figure (3): Postoperative angiography showing popliteo anterior tibial bypass.

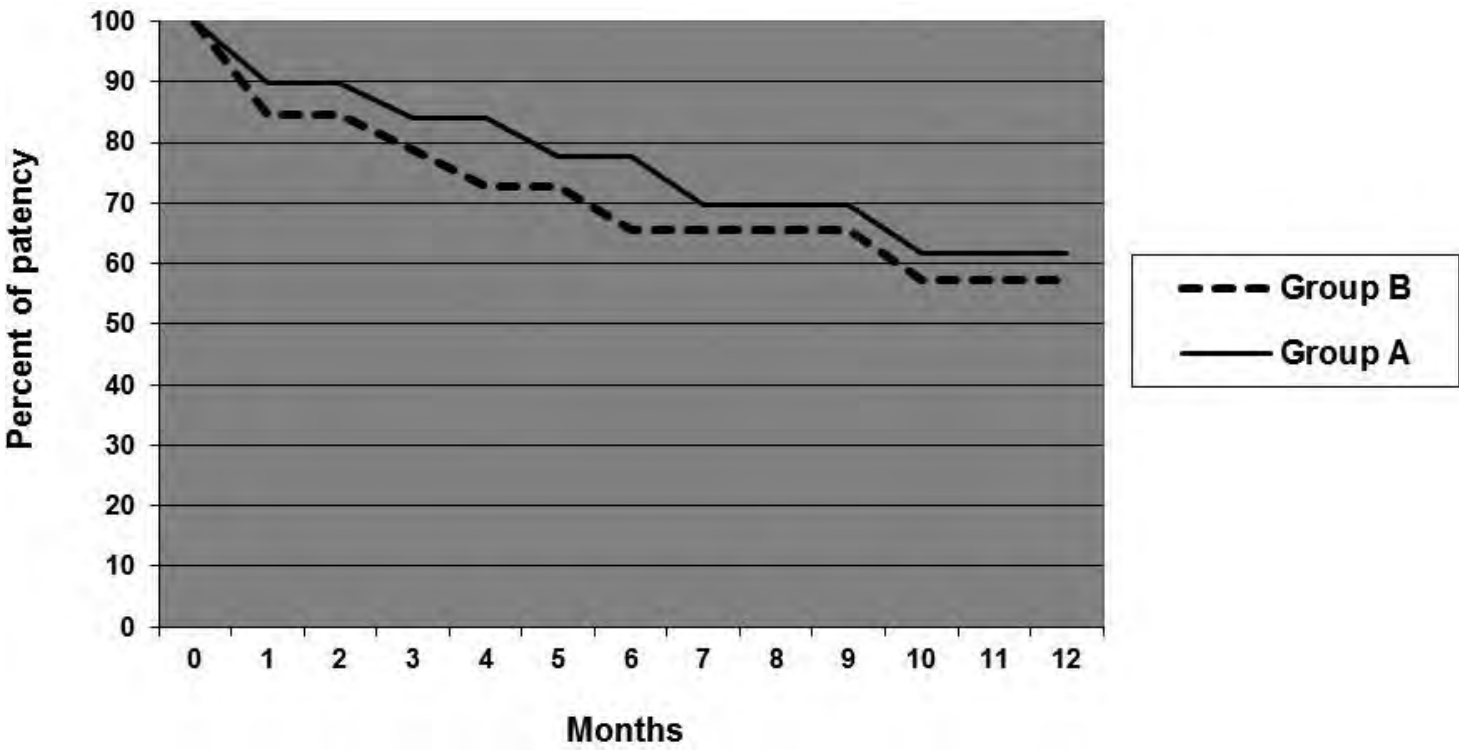

Figure (4): Primary patency in both groups. 


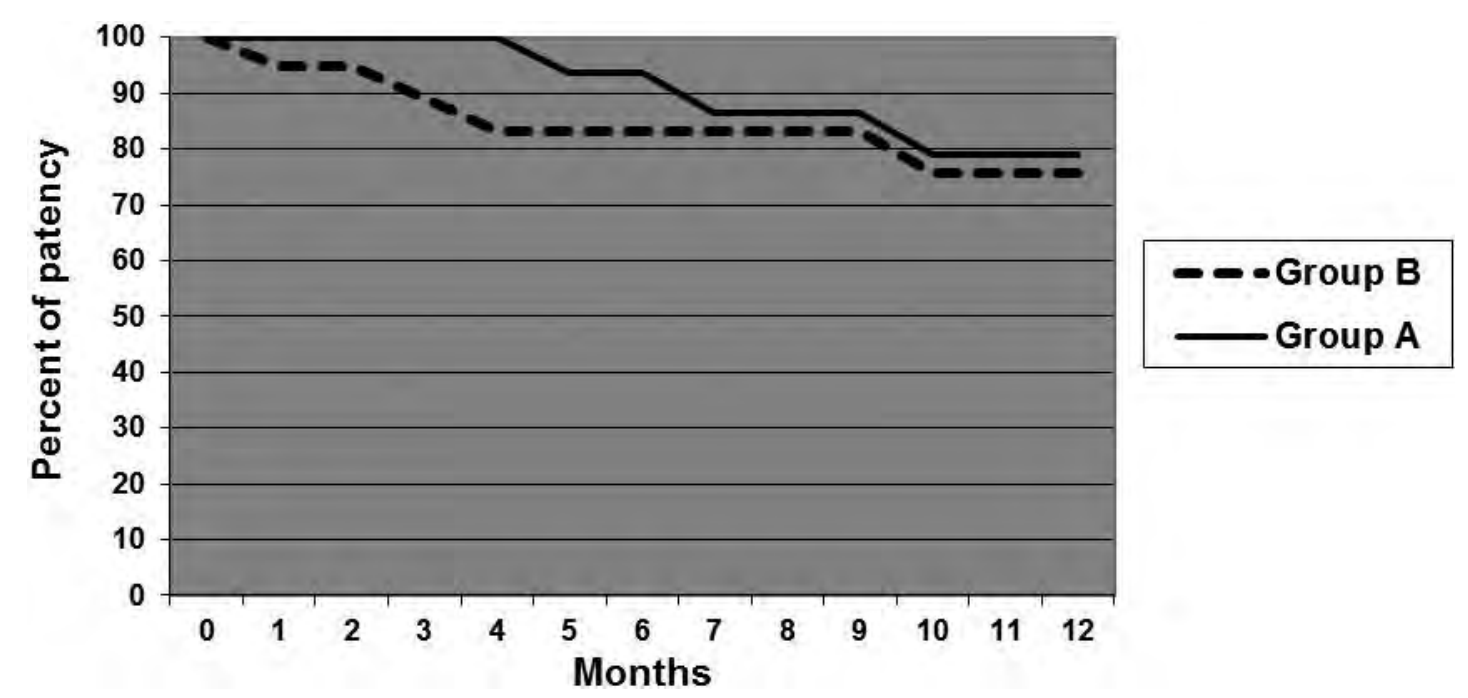

Figure (5): Secondary patency in both groups.

Table (1): The associated conditions in both groups of patients.

\begin{tabular}{|l|l|l|l|l|l|l|l|}
\hline \multirow{2}{*}{ Preoperative associated condition } & \multicolumn{2}{|l|}{ Group A } & \multicolumn{2}{l|}{ Group B } & X2 & \multirow{2}{*}{ p- value } \\
\cline { 2 - 7 } & $\mathrm{N}=20$ & $\%$ & $\mathrm{~N}=20$ & $\%$ & & \\
\hline $\begin{array}{l}\text { Previous lower limb surgical arterial } \\
\text { reconstruction or amputation }\end{array}$ & 2 & 10 & 1 & 5 & 0.360 & Ns \\
\hline Previous endovascular lower limb intervention & 1 & 15 & 2 & 10 & 0.228 & Ns \\
\hline Hypertension & 13 & 65 & 15 & 75 & 0.476 & Ns \\
\hline $\begin{array}{l}\text { Coronary artery disease (MI, CAGB, AP, or } \\
\text { ischaemia on ECG) }\end{array}$ & 11 & 55 & 13 & 65 & 0.416 & Ns \\
\hline Smoking & 12 & 60 & 14 & 70 & 0.439 & Ns \\
\hline Cerebrovascular (TIA or stroke) & 2 & 10 & 3 & 15 & 0.228 & Ns \\
\hline Renal insufficiency (S-creatinine> 2.5) & 2 & 10 & 1 & 5 & 0.360 & Ns \\
\hline Diabetes & 15 & 75 & 14 & 70 & 0.325 & Ns \\
\hline
\end{tabular}

$\mathrm{MI}=$ myocardial infarction; $\mathrm{CABG}=$ coronary artery bypass grafting; $\mathrm{AP}=$ angina pectoris;

$\mathrm{TIA}=$ transient ischemic attack, Ns $=\mathrm{p}>0.05$.

Table (2): Indications of surgery for patients in both groups.

\begin{tabular}{|c|c|c|c|c|c|c|}
\hline \multirow[t]{2}{*}{ Indication of surgery } & \multicolumn{2}{|c|}{$\begin{array}{l}\text { Group A } \\
\text { Total }=20\end{array}$} & \multicolumn{2}{|c|}{$\begin{array}{l}\text { Group B } \\
\text { Total }=20\end{array}$} & \multirow[t]{2}{*}{$\mathrm{X} 2$} & \multirow[t]{2}{*}{ p- value } \\
\hline & No & $\%$ & No & $\%$ & & \\
\hline Rest pain & 4 & 20 & 4 & 20 & 0.143 & $>0.05$ \\
\hline Ulceration & 5 & 25 & 3 & 15 & 0.173 & $>0.05$ \\
\hline Gangrene & 11 & 55 & 13 & 65 & 0.416 & $>0.05$ \\
\hline
\end{tabular}

was considered to indicate a failing graft.

Statistical analysis: In the statistical analysis, frequencies and categorical data of the two groups were compared using the chi-square test $\left(\mathrm{X}^{2}\right)$. A p value $<0.05$ was considered to be statistically significant. Primary and secondary patency rates and limb salvage rates for both groups were assessed with the Kaplan-Meier life table analysis method. 
Table (3): Ankle/ Brachial Index (Pre and Postoperatively).

\begin{tabular}{|l|l|l|}
\hline Ankle/ Brachial Index & Group A & Group B \\
\hline Preoperative mean ABI & 0.47 & 0.36 \\
\hline Preoperative range of ABI & $0.35: 0.6$ & $0.3: 0.65$ \\
\hline Postoperative mean ABI & 0.92 & 0.85 \\
\hline Postoperative range of ABI & $0.72: 1$ & $0.75: 0.95$ \\
\hline
\end{tabular}

Table (4): Preoperative and postoperative foot care procedures.

\begin{tabular}{|l|l|l|l|l|}
\hline Procedure & Group A & Group B & X2 & P value \\
\hline Preoperative & & & & \\
Local procedure: & & & & \\
Debridement & 1 & 0 & 1.02 & $>0.05$ \\
Drainage & 1 & 1 & 0.000 & $>0.05$ \\
\hline Postoperative & & & & \\
Local procedure: & 2 & 1 & 0.360 & \\
Debridement & 1 & 1 & 0.000 & $>0.05$ \\
Drainage & 0 & 2 & 0.000 & \\
Metatarsal head resection & & & & \\
& & & & \\
Minor amputation: & 5 & 6 & 0.125 & \\
Toe(s) & 4 & 4 & 0.000 & $>0.05$ \\
Transmetatarsal & 2 & 3 & 0.228 & \\
Partial calcanectomy & 2 & \multicolumn{4}{|l}{} \\
\hline
\end{tabular}

Table (5): Early (30 day) morbidity and mortality in Group A and Group B after surgery.

\begin{tabular}{|c|c|c|c|c|}
\hline Complications & Group A & Group B & $\mathrm{X} 2$ & $\mathrm{P}$ value \\
\hline $\begin{array}{l}\text { Total number } \\
\text { of patients with } \\
\text { complications }\end{array}$ & 7 & 4 & 0.416 & $>0.05$ \\
\hline $\begin{array}{l}\text { Total number of } \\
\text { complications }\end{array}$ & 12 & 6 & ........ & \\
\hline $\begin{array}{l}\text { Systemic } \\
\text { Cardiac } \\
\text { Respiratory } \\
\text { GIT } \\
\text { Renal } \\
\end{array}$ & $\begin{array}{l}2 \\
1 \\
1 \\
0\end{array}$ & $\begin{array}{l}2 \\
0 \\
0 \\
1 \\
\end{array}$ & ----- & ------ \\
\hline $\begin{array}{l}\text { Local } \\
\text { Wound seroma } \\
\text { Wound infection } \\
\text { External bleeding } \\
\text { Hematomas } \\
\text { Oedema }\end{array}$ & $\begin{array}{l}3 \\
2 \\
1 \\
1 \\
1\end{array}$ & $\begin{array}{l}0 \\
0 \\
0 \\
3 \\
0\end{array}$ & ---- & ---- \\
\hline Mortality & 2 & 1 & 0.360 & $>0.05$ \\
\hline
\end{tabular}

Patients may have developed more than one complication 
Table (6): Primary patency rate in group A using "Life table" analysis.

\begin{tabular}{|l|l|l|l|l|l|l|}
\hline \multicolumn{1}{|c|}{$\mathrm{A}$} & \multicolumn{1}{c|}{$\mathrm{B}$} & $\mathrm{C}$ & \multicolumn{1}{c|}{$\mathrm{D}$} & $\mathrm{E}$ & $\mathrm{F}$ & $\mathrm{G}$ \\
\hline $\begin{array}{c}\text { Interval } \\
\text { months }\end{array}$ & $\begin{array}{c}\mathrm{At} \\
\text { risk } \\
\text { grafts }\end{array}$ & $\begin{array}{c}\text { Failed } \\
\text { during } \\
\text { interval }\end{array}$ & $\begin{array}{c}\text { Withdrawn } \\
\text { during } \\
\text { interval }\end{array}$ & $\begin{array}{c}\text { Interval } \\
\text { failure } \\
\text { rate }\end{array}$ & $\begin{array}{c}\text { Cumulative } \\
\text { patency } \\
\text { rate }\end{array}$ & $\begin{array}{c}\text { Standard } \\
\text { error }\end{array}$ \\
\hline 0 to 0.5 & 20 & 2 & 1 & 0.102 & $89.9 \%$ & $6.38 \%$ \\
\hline 0.5 to 1 & 17 & 0 & 1 & 0.000 & $89.9 \%$ & $6.29 \%$ \\
\hline 1 to 2 & 16 & 0 & 0 & 0.000 & $89.9 \%$ & $7.14 \%$ \\
\hline 2 to 3 & 16 & 1 & 1 & 0.064 & $84.0 \%$ & 8.405 \\
\hline 3 to 4 & 14 & 0 & 1 & 0.000 & $84.0 \%$ & $8.90 \%$ \\
\hline 4 to 5 & 13 & 1 & 0 & 0.076 & $77.6 \%$ & $10.18 \%$ \\
\hline 5 to 6 & 12 & 0 & 2 & 0.000 & $77.6 \%$ & $10.60 \%$ \\
\hline 6 to 9 & 10 & 1 & 0 & 0.100 & $69.8 \%$ & $12.12 \%$ \\
\hline 9 to 12 & 9 & 2 & 1 & 0.117 & $64.6 \%$ & $12.72 \%$ \\
\hline
\end{tabular}

Table (7): Secondary patency rate in group A using "Life table" analysis.

\begin{tabular}{|l|l|l|l|l|l|l|}
\hline \multicolumn{1}{|c|}{ A } & \multicolumn{1}{c|}{$\mathrm{B}$} & \multicolumn{1}{c|}{ C } & \multicolumn{1}{c|}{$\mathrm{D}$} & \multicolumn{1}{c|}{$\mathrm{E}$} & \multicolumn{1}{c|}{$\mathrm{F}$} & $\mathrm{G}$ \\
\hline $\begin{array}{c}\text { Interval } \\
\text { months }\end{array}$ & $\begin{array}{c}\text { No.at } \\
\text { risk } \\
\text { grafts }\end{array}$ & $\begin{array}{c}\text { No. failed } \\
\text { during } \\
\text { interval }\end{array}$ & $\begin{array}{c}\text { Withdrawn } \\
\text { during } \\
\text { interval }\end{array}$ & $\begin{array}{c}\text { Interval } \\
\text { failure } \\
\text { rate }\end{array}$ & $\begin{array}{c}\text { Cumulative } \\
\text { patency rate }\end{array}$ & $\begin{array}{c}\text { Standard } \\
\text { error }\end{array}$ \\
\hline 0 to 0.5 & 20 & 0 & 1 & 0.000 & $100 \%$ & $0.00 \%$ \\
\hline 0.5 to 1 & 19 & 0 & 1 & 0.000 & $100 \%$ & $0.00 \%$ \\
\hline 1 to 2 & 18 & 0 & 0 & 0.000 & $100 \%$ & $0.00 \%$ \\
\hline 2 to 3 & 18 & 0 & 1 & 0.000 & $100 \%$ & $0.00 \%$ \\
\hline 3 to 4 & 17 & 0 & 1 & 0.000 & $100 \%$ & $0.00 \%$ \\
\hline 4 to 5 & 16 & 1 & 0 & 0.062 & $93.8 \%$ & $5.83 \%$ \\
\hline 5 to 6 & 15 & 0 & 2 & 0.000 & $93.8 \%$ & $6.03 \%$ \\
\hline 6 to 9 & 13 & 1 & 0 & 0.076 & $86.6 \%$ & $8.79 \%$ \\
\hline 9 to 12 & 12 & 1 & 1 & 0.086 & $79.1 \%$ & $10.43 \%$ \\
\hline
\end{tabular}

Table (8): Primary patency rate group B using "Life table” analysis.

\begin{tabular}{|l|l|l|l|l|l|l|}
\hline \multicolumn{1}{|c|}{ A } & \multicolumn{1}{c|}{ B } & \multicolumn{1}{c|}{ C } & \multicolumn{1}{c|}{$\mathrm{D}$} & \multicolumn{1}{c|}{$\mathrm{E}$} & \multicolumn{1}{c|}{$\mathrm{F}$} & $\mathrm{G}$ \\
\hline $\begin{array}{c}\text { Interval } \\
\text { months }\end{array}$ & $\begin{array}{c}\text { At risk } \\
\text { grafts }\end{array}$ & $\begin{array}{c}\text { Failed during } \\
\text { interval }\end{array}$ & $\begin{array}{c}\text { Withdrawn } \\
\text { during interval }\end{array}$ & $\begin{array}{c}\text { Interval } \\
\text { failure rate }\end{array}$ & $\begin{array}{c}\text { Cumulative } \\
\text { patency rate }\end{array}$ & $\begin{array}{c}\text { Standard } \\
\text { error }\end{array}$ \\
\hline 0 to 0.5 & 20 & 2 & 1 & 0.102 & $89.9 \%$ & $6.38 \%$ \\
\hline 0.5 to 1 & 17 & 1 & 0 & 0.058 & $84.5 \%$ & $8.06 \%$ \\
\hline 1 to 2 & 16 & 0 & 1 & 0.000 & $84.5 \%$ & $8.31 \%$ \\
\hline 2 to 3 & 15 & 1 & 1 & 0.068 & $78.8 \%$ & $8.65 \%$ \\
\hline 3 to 4 & 13 & 1 & 0 & 0.076 & $72.8 \%$ & $9.29 \%$ \\
\hline 4 to 5 & 12 & 0 & 2 & 0.000 & $72.8 \%$ & $9.67 \%$ \\
\hline 5 to 6 & 10 & 1 & 0 & 0.100 & $65.5 \%$ & $12.16 \%$ \\
\hline 6 to 9 & 9 & 0 & 1 & 0.000 & $65.5 \%$ & $12.82 \%$ \\
\hline 9 to 12 & 8 & 2 & 0 & 0.125 & $59.3 \%$ & $13.23 \%$ \\
\hline
\end{tabular}


Table (9): Secondary patency rate in group B using "Life table" analysis.

\begin{tabular}{|l|l|l|l|l|l|l|}
\hline \multicolumn{1}{|c|}{$\mathrm{A}$} & \multicolumn{1}{c|}{$\mathrm{B}$} & $\mathrm{C}$ & $\mathrm{D}$ & $\mathrm{E}$ & $\mathrm{F}$ & $\mathrm{G}$ \\
\hline $\begin{array}{c}\text { Interval } \\
\text { months }\end{array}$ & $\begin{array}{c}\text { No.at } \\
\text { risk } \\
\text { grafts }\end{array}$ & $\begin{array}{c}\text { No. failed } \\
\text { during } \\
\text { interval }\end{array}$ & $\begin{array}{c}\text { Withdrawn } \\
\text { during } \\
\text { interval }\end{array}$ & $\begin{array}{c}\text { Interval } \\
\text { failure } \\
\text { rate }\end{array}$ & $\begin{array}{c}\text { Cumulative } \\
\text { patency } \\
\text { rate }\end{array}$ & $\begin{array}{c}\text { Standard } \\
\text { error }\end{array}$ \\
\hline 0 to 0.5 & 20 & 0 & 1 & 0.000 & $100 \%$ & $0.00 \%$ \\
\hline 0.5 to 1 & 19 & 1 & 0 & 0.052 & $94.8 \%$ & $4.95 \%$ \\
\hline 1 to 2 & 18 & 0 & 1 & 0.000 & $94.8 \%$ & $5.09 \%$ \\
\hline 2 to 3 & 17 & 1 & 1 & 0.060 & $89.1 \%$ & $7.13 \%$ \\
\hline 3 to 4 & 15 & 1 & 0 & 0.066 & $83.2 \%$ & $8.80 \%$ \\
\hline 4 to 5 & 14 & 0 & 2 & 0.000 & $83.2 \%$ & $9.11 \%$ \\
\hline 5 to 6 & 12 & 0 & 0 & 0.000 & $82.3 \%$ & $9.84 \%$ \\
\hline 6 to 9 & 12 & 0 & 1 & 0.000 & $82.3 \%$ & $9.84 \%$ \\
\hline 9 to 12 & 11 & 1 & 0 & 0.090 & $75.7 \%$ & $11.25 \%$ \\
\hline
\end{tabular}

\section{Results:}

This study included 40 patients; 20 in group $A$ and 20 in group B. In group A the mean age was 53.2 years. They were 15 males and 5 females. 15 patients were diabetics. While in group $B$ the mean age of the patients was 57.8 years. They were 16 males and 4 females 14 of them were diabetics.

Indication for revascularization in both groups is shown in Table (2). According to the TASC types all patients in group A were TASC C\&D lesions, while in group $\mathrm{B}$ all lesions were type $\mathrm{C}$ only.

According to the site of runoff in group A cases, 14 popliteo - posterior tibial and 6 popliteo-anterior tibial bypasses were done. In 15 bypasses a reversed saphenous graft was used, while in the other 5 translocated saphenous graft was used.

In group $\mathrm{B}$ arterial duplex and/or angiography revealed that the lesions were: 7 anterior tibial, 16 posterior tibial and 9 tibio-peroneal.

In the first two weeks postoperatively in group A two patients died, one from cardiac and the other patient died from hypoglycemic attack. Another one died 3 months after the operation with massive myocardial infarction. There were four patients withdrawn from the study as one of them underwent above knee amputation, while the other three cases were missed from the follow up schedule.
Seven grafts were occluded in our study; two at the same day of operation, to which thrombectomy of the graft was done and the flow regained successfully. Another patient came to us around 3 months of the operation with no distal doppler signals, duplex study showed thrombosis of the entire graft, angiography was done and revealed significant stenosis of the external iliac artery (EIA), thrombectomy was done successfully with dilatation and stenting of the EIA. In the other four occluded grafts no further surgical interference was done as two of them had unsalvageable feet with infection reaching the site of distal anastomosis and underwent above knee amputation. Another one presented to us 8 months postoperatively with occluded graft and healed ulcer and was treated medically. The last case occluded after 10 months postoperatively and the patient presented with aggressive infection and unsalvageable foot and underwent above knee amputation.

In the first two weeks postoperatively one patient died of massive myocardial infarction. Another patient died at the 18 weeks postoperatively in car accident, and another one died 10 weeks postoperatively and the suggestive cause was unknown. There were four patients withdrawn from the study as two of them underwent major amputation. The other two cases were missed from the 
follow up schedule.

As regard group B, 8 procedures failed in our study; one at the same time of the procedure due to arterial perforation and the patient was transferred to surgery and the flow was regained successfully by interposition graft in posterior tibial artery. The 2nd case developed huge puncture site hematoma compressing CFA, surgical exploration 24 hours after the angioplasty was done with evacuation of hematoma and thrombectomy was done with restoration of blood flow. The third and fourth patients showed lost palpable pulsation on the 4th week and 3rd month respectively with ischaemic stump of toes amputations, CT angiography was done and showed restenosis in $3^{\text {rd }}$ case and occlusion in the 4th, redilatation was performed to the $3^{\text {rd }}$ and PD bypass to the $4^{\text {th }}$ case.

The fifth patient came to us after 4 months of the procedure with recurrence of rest pain, duplex study showed restenosis of the artery but no further surgical interference was done as there was unsalvageable feet and underwent major amputation. The sixth patient came to us 6 months postoperatively at the time of routine follow up duplex where there was restenosis with still good perfusion of the limb and was treated medically. The last two patients came to us at one year with occluded artery and neglected ischemic limb and underwent above knee amputation.

Four cases of Group A underwent major amputations, three of them showed occlusion of the bypass graft. The fourth patient was diabetic female patient complaining of forefoot gangrene and underwent posterior tibial bypass then after four months there was ascending infection reaching the level of malleoli with still pulsating graft so below knee amputation was done to the patient. After 10 days we noticed infection in the stump, drainage with repeated dressing was tried but lastly decision of above knee amputation was taken.

Five cases in Group B underwent major amputations; three of them showed occlusion of the procedure with neglected ischemic limb while the other two cases underwent amputations due to extension of infection and unsalvageable foot lesions.

\section{Discussion:}

Occlusive disease of the popliteal artery and its trifurcation with sparing of the superficial femoral artery is a pattern of atherosclerosis, which is often seen in patients with diabetes. These patients with single-level occlusive disease may have limb-threatening ischemia. We tested in this study the available treatment options for such patients: open surgery and PTA. Ballotta et al ${ }^{1}$ stated that infrapopliteal revascularization originating from the SFA or popliteal and tibial arteries can be carried out with patency and limb salvage rates statistically not different from those achieved with revascularization arising from the CFA.

In this study group A patients were offered popliteo-distal bypass in which 14 popliteo - posterior tibial and 6 popliteoanterior tibial bypasses were done, where the posterior tibial and anterior tibial arteries provided a straight line flow to the foot. The peroneal and dorsalis pedis arteries were not used as an outflow in any case of this study. Albers et al ${ }^{12}$ stated in a meta-analysis of 31 studies that when a dorsal pedal bypass and a peroneal bypass are both applicable, some surgeons prefer the dorsal pedal bypass to obtain more complete foot revascularization and avoid major amputation in the presence of a patent graft. ${ }^{13}$ A properly indicated tibial or peroneal bypass is possibly as effective as a longer pedal bypass for limb salvage. ${ }^{14}$ The GSV was used as a conduit in all patients of group A. Many studies followed the same principle. ${ }^{15-17}$

Fifteen patients in this study had a reversed saphenous conduit while 5 patients had non reversed translocated saphenous graft used due to size mismatch especially at the distal anastomoses. Most studies on PD grafts have shown a preference for the reversed configuration. ${ }^{18}$ One study used the non-reversed translocated GSV in 15\% of the cases until 1989 and in 31\% thereafter. The non-reversed translocated GSV is sometimes particularly suitable for infrapopliteal revascularization. 19

Primary success was achieved in 13/20 
patients of group A in this study (65\%). Primary success rates of other studies concerned with short bypasses worldwide showed a wide range between $60 \%$ (in patients with severe calcifications), ${ }^{20} 74 \%$ (in patients with no calcification) and up to $93 \%$ in a meta-analysis of 31 studies. ${ }^{12}$ The differences between studies are probably related to technical experience, and selection criteria of patients and differences in the quality of the run off. Limb salvage rate in group A was $80 \%$ (16/20) patients). This was comparable to other studies as Albers et al ${ }^{12}$ $88 \%$, Ballotta et al ${ }^{1} 95 \%$, Chung et al $2185 \%$, and Hughes et al ${ }^{22} 75 \%$, Sayed et al ${ }^{23} 85 \%$.

Group B patients were offered a percutaneous transluminal angioplasty to revascularize their infrapopliteal disease. The site of the lesion to be dilated was 7 anterior tibial, 16 posterior tibial, and 9 tibio-peroneal. The aim of the procedure was to obtain a straight-line flow to the foot. Beyssen et $\mathrm{al}^{24}$ stressed the importance of obtaining a straight-line flow to the foot and treating all the significant stenoses and short occlusions that impair distal vascularization. Primary success was achieved in 12/20 patients of group A $60 \%$. Bosiers et $\mathrm{al}^{25}$ reported similar results: $68 \%$, also Sayed et al $^{23}$ reported similar results $64 \%$. But Sigala et al ${ }^{26}$ reported better results: $94 \%$, but this is explained by the fact that their patients were not restricted to TASC C\&D disease, so, patients with milder lesions (TASC group A \& B) had better results.

Limb salvage rate in patients of group B was 75\% (15/20patients). It was higher in Sayed et al $2378 \%$, and also higher in Bosiers et al 25 $96.7 \%$ and Sigala et $\mathrm{al}^{26} 92 \%$, but again these higher values are explained by the presence of lesions of all categories in these studies. In fact, Sigala et $\mathrm{al}^{26}$ reported significantly higher amputation rates in patients falling into TASC group C. In addition, our study selected patients with a contraindication to open surgery, as spreading infection near the site of run off, to do PTA. one of these patients had a BKA done due to the infection, in spite, of patent artery, which reduced the limb salvage rate.
It is worth noting that 4 patients in group B had their limbs saved inspite of occlusion of their arteries. This can be explained by the fact that once healing has occurred, should the artery restenose or occlude, collateral flow can be sufficient to preserve tissue integrity if there is no further injury.

Patients with critical limb ischemia are typically elderly with multiple co-morbidities and limited life expectancy and therefore, a procedure, which is minimally invasive with reduced morbidity and mortality but lesser longterm patency, may be more appropriate than a more invasive procedure with better long-term patency. ${ }^{27}$ Amato et al reported similarly the particular suitability of PTA for the elderly patients. ${ }^{28}$

No stents were used in this study, because the experience in their use in infrapopliteal disease is still evolving and currently insufficient to justify their primary use, subinitimal technique was not used in this study, but Bolia reported in 2005 that recanalization of long tibial occlusions and the possibility of reconstituting the trifurcation has proved to be most useful in the treatment of patients with critical limb ischemia. ${ }^{29}$

\section{Conclusion:}

Although infragenicular PTA still has less primary success rate and limb salvage rates than PD bypass, it is a very promising technique in our institute owing to its lower rate of perioperative morbidity plus our growing experience.

\section{Reference}

1- Ballotta E, Renon L, Rossi A, Barbon B, Terranova O, Giau G: Prospective randomized study on reversed saphenous vein infrapopliteal bypass to treat limbthreatening ischemia: Common femoral artery versus superficial femoral or popliteal and tibial arteries as inflow. J Vasc Surg 2004; 40: 732-740.

2- Christopher D: Adaptive changes in autogenous vein grafts for arterial reconstruction: Clinical implications. J Vasc Surg 2010; 51: 736-746.

3- Norgreen L, Hiatt WR, Dormandy JA, et al: Inter-Society Consensus for the 
management of peripheral arterial disease (TASC II). Eur J Vasc Endovasc Surg 2007; 33(Suppl 1): S32-S55.

4- Blevins WA, Schneider PA: Endovascular management of critical limb ischemia. Eur $J$ Vasc Endovasc Surg 2010; 39: 756-761.

5- Conrad MF, Kang J, Cambria RP, et al: Infrapopliteal balloon angioplasty for the treatment of chronic occlusive disease. $J$ Vasc Surg 2009; 50: 799-805.

6- Romiti M, Albers M, Brochado-Neto FC, et al: Meta-analysis of infrapopliteal angioplasty for chronic critical limb ischemia. J Vasc Surg 2008; 47: 975-981.

7- Adam DJ, Beard JD, Cleveland T, et al: BASIL trial participants. Bypass versus angioplasty in severe ischemia of the leg (BASIL): Multicentre, randomized controlled trial. Lancet 2005; 366: 1925-1934.

8- Markose G, Bolia A: Below the knee angioplasty among diabetic patients. $J$ Cardiovasc Surg (Torino) 2009; 50: 323-329.

9- Faglia E, Mantero M, Caminiti M, et al: Extensive use of peripheral angioplasty, particularly infrapopliteal, in the treatment of ischemic diabetic foot ulcers: Clinical results of a multicentric study of 221 consecutive diabetic subjects. J Intern Med 2002; 252: 225-232.

10- TransAtlantic Inter-Society Consensus (TASC) Working Group: Management of peripheral arterial disease. J Vasc Surg 2000; 31: S99.

11- Rutherford R, Baker J, Ernst C, Johnston K, Porter J, Ahn S, Jones D: Recommended standards for reports dealing with lower extremity ischemia. Revised version J Vasc Surg 1997; 26: 33.

12- Albers M, Romiti, M, Cardoso F, Neto B, De Luccia N, Pereira C: Meta-analysis of popliteal-to-distal vein bypass grafts for critical ischemia. J Vasc Surg 2006; 43: 498-503.

13- Stonebridge PA, Tsoukas AI, Pomposelli FB, Gibbons GW, Campbell DR, Freeman DV, et al: Popliteal-to-distal bypass grafts for limb salvage in diabetics. Eur J Vasc Surg 1991; 5:265-269.

14- Abou-Zamzam AM Jr, Moneta GL, LeeRW, Nehler MR, Taylor LM Jr, Porter JM: Peroneal bypass is equivalent to inframalleolar bypass for ischemic pedal gangrene. Arch Surg 1996; 131: 894-898.

15- Schneider PA, Caps MT, Ogawa DY, Hayman ES: Intraoperative superficial femoral artery balloon angioplasty and popliteal to distal bypass graft: an option for combined open and endovascular treatment of diabetic gangrene. J Vasc Surg 2001; 33: 955-962.

16- Ballard JL, Killeen JD, Bunt TJ, Malone JM: Autologous saphenous vein poplitealtibial artery bypass for limb-threatening ischemia: A reassessment. Am J Surg 1995; 170: 251-255.

17- Marks J, King TA, Baele H, Rubin J, Marmen C: Popliteal-to-distal bypass for limb-threatening ischemia. J Vasc Surg 1992; 15: 755-759.

18- Goyal A, Shah PM, Babu SC, Mateo RB: Popliteal-crural bypass through the posterior approach with lesser saphenous vein for limb salvage. J Vasc Surg 2002; 36: 708-712.

19- Pomposelli FB, Kansal N, Hamdan AD, Belfield A, Sheahan M, Campbell DR, et al: A decade of experience with dorsalis pedis artery bypass: Analysis of outcome in more than 1000 cases. J Vasc Surg 2003; 37: 307-315.

20- Hicks RC, Moss DJ, Higman DJ, Greenhalgh RM, Powell JT: The influence of diabetes on the vasomotor responses of saphenous vein and the development of infrainguinal graft stenosis. Diabetes 1997; 46: 113-118.

21- Chung J, Bartelson BB, Hiatt WR, Peyton, BD, McLafferty RB, Hopley CW, Salter KD, Nehler MR: Wound healing and functional outcomes after infrainguinal bypass with reversed saphenous vein for critical limb ischemia. J Vasc Surg 2006;43: 1183-1190.

22- Hughes K, Domenig CM, Hamdan AD, Schermerhorn M, Aulivola B, Blattman S, Campbell DR, Scovell SD, LoGerfo FD, Pomposelli FB, Jr: Bypass to plantar and tarsal arteries: An acceptable approach to limb salvage. J Vasc Surg 2004; 40: 1149-1157.

23- Sayed A, Elkashef O: Popliteal-to-Distal (PD) bypass vs infrapopliteal PTA: What is the appropriate treatment for infrapopliteal disease? Kasr El Aini. Journal of Surgery 2007; 8(2): 1-10.

24- Beyssen B, Pagny JY, Piquois A, Raynaud A, Sapoval M: Critical limb ischaemia: Endovascular treatment in diabetic patients. Arch Mal Coeur Vaiss. 2004; 97(3): 33-39

25- Bosiers M, Hart JP, Deloose K, Verbist J, Peeters P: Endovascular therapy as the primary approach for limb salvage in patients with critical limb ischemia: Experience with 443 infrapoplitealprocedures. Vascular 2006; 
14(2): 63-69.

26- Sigala F, Menenakos Ch, Sigalas P, Baunach Ch, Langer S, Papalambros E, Hepp W: Transluminal angioplasty of isolated crural arterial lesions in diabetics with critical limb ischemia. Vasa 2005; 34(3): 186-191.

27- Tsetis D, Belli M: The role of infrapopliteal angioplasty. $B r \quad J$ Radiol 2004; 77(924): 1007-1015.
28- Amato B, Iuliano GP, Markabauoi AK, Piscitelli V, Masone S, Compagna R, Esposito G, Piscione F: Endovascular procedures in critical leg ischemia of elderly patients. Acta Biomed Ateneo Parmense. 2005; 76(1): 11-15

29- Bolia A: Subintimal angioplasty in lower limb ischaemia. J Cardiovasc Surg (Torino). 2005; 46(4): 385-394. 